SURVEYING FOR ENGINEERS 


\section{OTHER MACMILLAN TITLES FOR ENGINEERS}

Civil Engineering Contract Administration and Control, 2nd Edition I.H. Seeley

Civil Engineering Materials, 4th Edition N. Jackson and R. Dhir

Civil Engineering Quantities, 5th Edition I.H. Seeley

Fundamental Structural Analysis W.J. Spencer

Practical Soil Mechanics

G. Barnes

Reinforced Concrete Design, 4th Edition W.H. Mosley and J.H. Bungey

Structural Mechanics

J. Cain and R. Hulse

Understanding Hydraulics

L. Hamill

Understanding Structures

Derek Seward 


\title{
Surveying for Engineers
}

\author{
J. UREN \\ Department of Civil Engineering \\ University of Leeds \\ W.F. PRICE \\ Department of Civil Engineering \\ University of Brighton
}

Third Edition

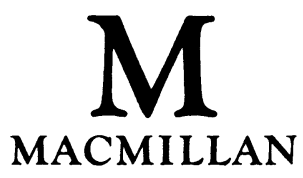


All rights reserved. No reproduction, copy or transmission of this publication may be made without written permission.

No paragraph of this publication may be reproduced, copied or transmitted save with written permission or in accordance with the provisions of the Copyright, Designs and Patents Act 1988, or under the terms of any licence permitting limited copying issued by the Copyright Licensing Agency, 90 Tottenham Court Road, London W1P 9HE.

Any person who does any unauthorised act in relation to this publication may be liable to criminal prosecution and civil claims for damages.

First edition 1978

Reprinted five times

Second edition 1985

Reprinted nine times

Third edition first published 1994 by

THE MACMILLAN PRESS LTD

Houndmills, Basingstoke, Hampshire RG21 2XS

and London

Companies and representatives

throughout the world

ISBN 978-0-333-57705-9 ISBN 978-1-349-12950-8 (eBook)

DOI 10.1007/978-1-349-12950-8

A catalogue record for this book is available from the British Library. 


\section{Contents}

Preface to the Third Edition xiii

Acknowledgements $\quad$ xv

1 Introduction 1

1.1 Surveying Institutions 1

$\begin{array}{ll}1.2 & \text { What is Surveying? }\end{array}$

1.3 Land Surveying 4

1.4 Engineering Surveying $\quad 6$

$\begin{array}{llr}1.5 & \text { Coordinate Systems } & 9\end{array}$

$\begin{array}{lll}1.6 & \text { Scale } & 15\end{array}$

$\begin{array}{lll}1.7 & \text { Units } & 17\end{array}$

$\begin{array}{lll}1.8 & \text { Surveying Computations } & 18\end{array}$

1.9 The Ordnance Survey 21

1.10 Aims and Limitations of this Book 29

Further Reading $\quad 30$

2 Levelling $\quad 31$

2.1 Level and Horizontal Lines 31

2.2 Datums and Bench Marks 33

2.3 Automatic Levels $\quad 34$

2.4 The Surveying Telescope 35

$\begin{array}{lll}2.5 & \text { Parallax } & 36\end{array}$

$\begin{array}{lll}2.6 & \text { The Compensator } & 37\end{array}$

2.7 Use of the Automatic Level 38

2.8 The Tilting Level 40

2.9 Use of the Tilting Level 42

2.10 The Digital Level 42

2.11 Permanent Adjustment of the Level 44

2.12 The Levelling Staff 49

2.13 Principles of Levelling $\quad 50$

2.14 Field Procedure $\quad 52$

2.15 Booking and Reduced Level Calculations 53 
2.16 Precision of Levelling 56

2.17 Errors in Levelling $\quad 57$

2.18 Summary of the Levelling Fieldwork 61

2.19 Additional Levelling Methods $\quad 62$

2.20 Applications of Levelling: Sectioning 64

2.21 Use of the Digital Level in Sectioning 67

$\begin{array}{ll}2.22 \text { Contouring } & 70\end{array}$

$\begin{array}{lll}2.23 & \text { Direct Contouring } & 70\end{array}$

$\begin{array}{ll}2.24 & 71\end{array}$

$\begin{array}{lll}2.25 & 73\end{array}$

2.26 Obtaining Sections from Contours 75

3 Theodolites and their Use $\quad 78$

$\begin{array}{lll}3.1 & \text { Principles of Angle Measurement } & 79\end{array}$

3.2 Basic Components of an Optical Theodolite 80

3.3 Circle Reading Methods 86

3.4 Electronic Theodolites $\quad 92$

3.5 Single and Dual-axis Compensators 100

$\begin{array}{lll}3.6 & \text { Setting Up a Theodolite } & 103\end{array}$

$\begin{array}{lll}3.7 & \text { Measuring Angles } & 107\end{array}$

3.8 Booking and Calculating Angles 112

3.9 Importance of Observing Procedure 114

$\begin{array}{lll}3.10 & \text { Effect of Miscentring a Theodolite } & 114\end{array}$

3.11 Height Measurement by Theodolite (Trigonometrical 115

3.12 Adjustments of a Theodolite 119

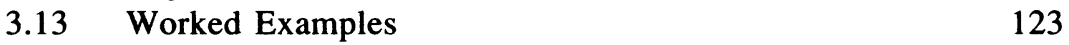

4 Distance Measurement: Taping and Stadia Tacheometry 127

$\begin{array}{lll}4.1 & \text { Direct Distance Measurement } & 128\end{array}$

$\begin{array}{lll}4.2 & \text { Steel Tapes } & 129\end{array}$

4.3 Steel Taping: Fieldwork 130

4.4 Steel Taping: Corrections 131

4.5 Steel Taping: Precision and Applications 137

4.6 Steel Taping: Worked Examples 138

4.7 Other Types of Tape 143

4.8 Optical Distance Measurement (ODM) 144

4.9 Stadia Tacheometry 144

4.10 Worked Example 145

4.11 Accuracy and Sources of Error in Stadia Tacheometry 147

4.12 Applications of Stadia Tacheometry 148

5 Distance Measurement: EDM and Total Stations 149

$\begin{array}{lll}5.1 & \text { Electromagnetic Waves } & 150\end{array}$ 
5.2 Phase Comparison

5.3 Analogy with Taping 153

5.4 Measurement Requirements 154

$\begin{array}{lll}5.5 & 155\end{array}$

5.6 EDM Reflectors 157

$\begin{array}{lll}5.7 & 159\end{array}$

$\begin{array}{lll}5.8 & \text { Theodolite-mounted EDM Systems } & 161\end{array}$

$\begin{array}{lll}5.9 & \text { Total Stations } & 163\end{array}$

$\begin{array}{lll}5.10 & \text { Features of Total Stations } & 163\end{array}$

$\begin{array}{lll}5.11 & 168\end{array}$

5.12 Total Stations: What to do and what not to do 174

$\begin{array}{ll}5.13 & \text { Specialised Total Stations } \\ 5.14\end{array}$

$\begin{array}{lll}5.14 & \text { Distancers } & 178\end{array}$

$\begin{array}{lll}5.15 & \text { Electronic Data Recording } & 180\end{array}$

$\begin{array}{lll}5.16 & \text { Timed-pulse Distance Measurement } & 188\end{array}$

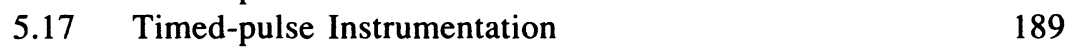

$\begin{array}{lll}5.18 & 192\end{array}$

5.19 Atmospheric Effects 192

5.20 Instrumental Errors 193

$\begin{array}{lll}5.21 & \text { EDM Calibration } & 194\end{array}$

$\begin{array}{ll}5.22 \text { Geometric Corrections } & 195\end{array}$

$\begin{array}{lll}5.23 & \text { Scale Factor } & 197\end{array}$

5.24 Measuring Reduced Levels Using EDM 199

5.25 Applications of EDM 200

6 Measurements and Errors $\quad 202$

6.1 Types of Error 202

6.2 Least Squares Estimation and Most Probable Value 204

6.3 Standard Deviation and Standard Error 205

6.4 Significance of the Standard Error 207

6.5 Worked Example 207

$\begin{array}{lll}6.6 & \text { Redundancy } & 209\end{array}$

6.7 Precision, Accuracy and Reliability 210

$\begin{array}{ll}6.8 & \text { Propagation of Standard Errors } \\ 6.910\end{array}$

$\begin{array}{ll}6.9 & \text { Worked Examples } \\ 6.10 & 212\end{array}$

6.10 Propagation of Errors in Survey Methods 215

$\begin{array}{lll}6.11 & \text { Survey Specifications } & 221\end{array}$

Further Reading $\quad 224$

7 Control Surveys $\quad 225$

$\begin{array}{lll}7.1 & \text { Types of Traverse } & 225\end{array}$

$\begin{array}{lll}7.2 & \text { Traverse Specifications and Accuracy } & 227\end{array}$

7.3 Traversing Fieldwork: Reconnaissance 228

$\begin{array}{lll}7.4 & \text { Station Marking } & 229\end{array}$ 
7.5 Traversing Fieldwork: Angular Measurement 230

7.6 Traversing Fieldwork: Distance Measurement 231

$\begin{array}{lll}7.7 & \text { Three-tripod Traversing } & 231\end{array}$

$\begin{array}{lll}7.8 & \text { Abstract of Fieldwork } & 233\end{array}$

$\begin{array}{lll}7.9 & \text { Angular Misclosure } & 234\end{array}$

7.10 Calculation of Whole-circle Bearings 235

7.11 Computation of Coordinate Differences 238

$\begin{array}{ll}7.12 \text { Misclosure } & 240\end{array}$

7.13 Distribution of the Misclosure 242

7.14 Calculation of the Final Coordinates 244

\begin{tabular}{ll}
7.15 & The Traverse Table \\
\hline
\end{tabular}

$\begin{array}{lll}7.16 & \text { Worked Examples } & 246\end{array}$

$\begin{array}{lll}7.17 & \text { Triangulation and Trilateration } & 252\end{array}$

$\begin{array}{lll}7.18 & \text { Network Configurations } & 253\end{array}$

7.19 Triangulation and Trilateration: Fieldwork 254

$\begin{array}{lll}7.20 & \text { Network Computations: Least Squares } & 258\end{array}$

7.21 Network Computations: Equal Shifts 259

$\begin{array}{lll}7.22 & \text { Worked Example } & 259\end{array}$

$\begin{array}{lll}7.23 & \text { Worked Example } & 263\end{array}$

$\begin{array}{lll}7.24 & \text { Intersection and Resection } & 266\end{array}$

7.25 Intersection by Solution of Triangle 269

$\begin{array}{lll}7.26 & \text { Intersection Using Angles } & 270\end{array}$

$\begin{array}{lll}7.27 & \text { Intersection Using Bearings } & 270\end{array}$

$\begin{array}{ll}7.28 & \text { Intersection from Two Baselines } \\ 7\end{array}$

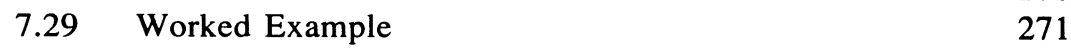

$\begin{array}{lll}7.30 & \text { Angular Resection } & 273\end{array}$

$\begin{array}{lll}7.31 & \text { Worked Example } & 274\end{array}$

$\begin{array}{lll}7.32 & \text { Distance Resection } & 277\end{array}$

8 Satellite Position Fixing Systems 278

$\begin{array}{lll}8.1 & \text { GPS Space Segment } & 279\end{array}$

8.2 GPS Control and User Segments 280

8.3 GPS Positioning Methods: Pseudo-ranging 281

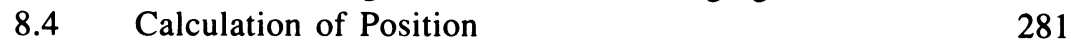

8.5 Ionospheric and Atmospheric Effects 282

$\begin{array}{lll}8.6 & \text { Accuracy Denial } & 283\end{array}$

8.7 Differential GPS 283

8.8 GPS Positioning Methods: Carrier Phase Measurements 284

8.9 Precise Differential Positioning and Surveying 285

$\begin{array}{lll}8.10 & \text { GPS Coordinates and Heights } & 288\end{array}$

$\begin{array}{lll}8.11 & \text { GPS Instrumentation } & 289\end{array}$

8.12 Applications of GPS 291 
9 Detail Surveying and Plotting

9.1 Principles of Plan Production 293

9.2 Specifications for Detail Surveys 294

9.3 Drawing Paper and Film 296

9.4 Plotting the Control Network 299

$\begin{array}{lll}9.5 & \text { Detail } & 303\end{array}$

$\begin{array}{lll}9.6 & \text { Offsets and Ties } & 305\end{array}$

9.7 Radiation by Stadia Tacheometry 308

9.8 Radiation Using a Theodolite and Tape 312

9.9 Radiation Using EDM Equipment and Total Stations 312

9.10 The Completed Survey Plan 315

9.11 Computer-Aided Plotting 320

9.12 Digital Terrain Models (DTMs) 327

Further Reading $\quad 330$

10 Circular Curves $\quad 331$

10.1 Types of Circular Curve 332

10.2 Terminology of Circular Curves 332

10.3 Important Relationships in Circular Curves 333

10.4 Useful Lengths $\quad 334$

10.5 Radius and Degree Curves 334

10.6 Length of Circular Curves $\left(L_{c}\right) \quad 335$

$\begin{array}{lll}10.7 & \text { Through Chainage } & 335\end{array}$

10.8 A Design Method for Circular Curves 336

10.9 The Use of Computers in the Design Procedure 337

10.10 Establishing the Centre Line on Site 338

10.11 Location of the Intersection and Tangent Points
in the Field

10.12 Location of the Tangent Points when the Intersection

10.13 Setting Out Circular Curves by Traditional Methods 341

10.14 Setting Out Circular Curves by Coordinate Methods 346

10.15 Obstructions to Setting Out 347

10.16 Plotting the Centre Line on a Drawing 348

10.17 Compound Circular Curves 348

10.18 Reverse Circular Curves $\quad 349$

10.19 Summary of Circular Curves $\quad 350$

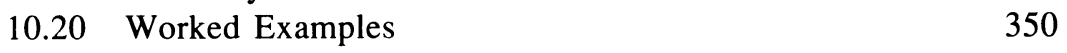

Further Reading $\quad 357$

11 Transition Curves $\quad 358$

11.1 Radial Force and Design Speed 358 
11.2 Superelevation 360

11.3 Current Department of Transport Design Standards 362

11.4 Use of the Design Standards 362

11.5 Use of Transition Curves 364

11.6 Length of Transition Curve to be Used $\left(L_{\mathrm{T}}\right)$

11.7 Type of Transition Curve to be Used 366

11.8 The Clothoid 366

11.9 The Cubic Parabola 369

11.10 Choice of Transition Curve $\quad 373$

11.11 The Shift of a Cubic Parabola 373

11.12 Tangent Lengths and Curve Lengths 375

11.13 Establishing the Centre Line on Site 376

11.14 Locating the Tangent Points on the Straights (T and U) 377

11.15 Setting Out the Curves by Traditional Methods 377

11.16 Setting Out the Curves by Coordinate Methods 379

11.17 Coordinate Methods Compared with Traditional Methods 381

11.18 Plotting the Centre Line on a Drawing 382

11.19 A Design Method for Composite Curves 383

11.20 A Design Method for Wholly Transitional Curves 385

11.21 Phasing of Horizontal and Vertical Alignments 387

11.22 Summary of Horizontal Curve Design 388

11.23 Computer-Aided Road Design 389

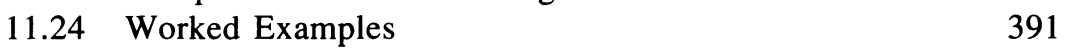

Further Reading $\quad 403$

12 Vertical Curves $\quad 404$

12.1 Gradients 404

12.2 Purposes of Vertical Curves 406

12.3 Type of Curve Used 406

12.4 Assumptions Made in Vertical Curve Calculations 407

12.5 Equation of the Vertical Curve 407

12.6 Sight Distances $\quad 409$

$\begin{array}{lll}12.7 & K \text {-values } & 410\end{array}$

12.8 Use of $K$-values 411

12.9 Length of Vertical Curve to be Used $\left(L_{\mathrm{v}}\right) \quad 413$

12.10 Phasing of Vertical and Horizontal Alignments 413

12.11 Plotting and Setting Out the Vertical Curve 414

12.12 Highest Point of a Crest, Lowest Point of a Sag 415

12.13 Summary of Vertical Curve Design 416

12.14 Vertical Curves with Unequal Tangent Lengths 416

12.15 Computer-Aided Road Design 417

12.16 Worked Examples 418

Further Reading $\quad 422$ 
13.1 Units 424

13.2 Areas Enclosed by Straight Lines 424

13.3 Areas Enclosed by Irregular Lines 428

13.4 The Planimeter 431

13.5 Longitudinal Sections and Cross-sections 434

13.6 Cross-sections on Horizontal Ground 438

13.7 Two-level Cross-sections 439

13.8 Three-level Cross-sections 440

13.9 Cross-sections Involving both Cut and Fill 442

13.10 Irregular Cross-sections 445

13.11 Using the Cross-sectional Areas and Side Widths 446

13.12 Volumes from Cross-sections 446

13.13 Combined Cross-sectional Area and Volume Calculations 453

13.14 Volumes from Spot Heights 456

13.15 Volumes from Contours 457

13.16 Introduction to Mass Haul Diagrams 459

13.17 Formation Level and the Mass Haul Diagram 460

13.18 Drawing the Diagram 460

13.19 Terminology of Mass Haul Diagrams 463

13.20 Properties of the Mass Haul Curve 463

13.21 Economics of Mass Haul Diagrams 465

13.22 Choice of Balancing Line 467

13.23 Uses of Mass Haul Diagrams 471

13.24 Computer-Aided Earthwork Calculations 472

Further Reading $\quad 474$

14 Setting Out $\mathbf{4 7 5}$

14.1 Personnel Involved in Setting Out and Construction 476

14.2 Aims of Setting Out 478

14.3 Plans and Drawings Associated with Setting Out 479

14.4 Good Working Practices when Setting Out 480

14.5 Stages in Setting Out 486

14.6 Methods of Horizontal Control 487

14.7 Methods of Vertical Control 492

14.8 Positioning Techniques 504

14.9 Setting Out a Pipeline 507

14.10 Setting Out a Building to Ground-floor Level 512

14.11 Transfer of Control to Ground-floor Slab 513

14.12 Setting Out Formwork 513

14.13 Setting Out Column Positions 514

14.14 Controlling Verticality 515 
14.15 Transferring Height from Floor to Floor 525

14.16 Setting Out Using Laser Instruments 526

14.17 Applications of Setting Out from Coordinates 537

14.18 Quality Assurance and Accuracy in Surveying and Setting Out

14.19 Worked Examples $\quad 548$ Further Reading $\quad 552$

15 Deformation Monitoring 554

15.1 Vertical Movement $\quad 555$

15.2 Worked Example $\quad 558$

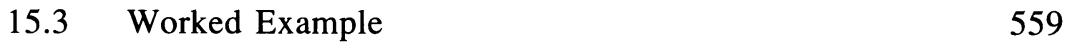

$\begin{array}{lll}15.4 & \text { Horizontal Movement } & 561\end{array}$

15.5 Control Networks for Monitoring 561

$\begin{array}{lll}15.6 & \text { Intersection } & 562\end{array}$

$\begin{array}{lll}15.7 & \text { Bearing and Distance } & 563\end{array}$

15.8 Coordinate Measuring Systems $\quad 565$

15.9 Leica ECDS Coordinate Measuring System 566

15.10 Sokkia MONMOS Coordinate Measuring System 569 Further Reading $\quad 571$

$\begin{array}{ll}\text { Index } & 572\end{array}$ 


\section{Preface to the Third Edition}

Since the publication of the second edition of Surveying for Engineers, much of the instrumentation now used by surveyors and engineers on site is electronic, especially theodolites, EDMs and total stations. Through the use of computers, electronic data acquisition and processing is now well established and there is a much greater emphasis on quality in surveying with the introduction of BS5750 and other similar standards.

When writing this third edition, we have attempted to reflect the changes occurring in current practice by introducing new chapters and revising others. This, together with the basic techniques of surveying, provide a book with an easy-to-read format that covers the equipment and methods essential for modern site surveying.

New chapters have been introduced dealing with measurements and errors, the global positioning system and deformation monitoring, all of which have gained prominence in engineering surveying in recent years.

Amongst other changes to the third edition are an extended introductory chapter, the chapters dealing with levelling and theodolites have been revised and the original chapter on distance measurement has been made into two separate chapters on taping and EDM/total stations. Methods of providing control on site are now dealt with in one chapter and the setting out chapter has been extended to include quality assurance.

Throughout the text, computerised surveying and associated software are discussed in some detail, especially those used for mapping and for applications in horizontal and vertical curves.

Although the book has been written with civil engineering students in mind, it is hoped that it will also be found useful by practising engineers as well as by any other students who undertake engineering surveying as a subsidiary subject.

The text covers engineering surveying up to the end of virtually all university first-year and most second-year degree courses in civil and environmental engineering, building, construction, engineering geology and other related disciplines and BTEC courses from level III at colleges of technology 


\section{Acknowledgements}

The authors wish to thank all those who have contributed in any way to the preparation of this book and, in particular, the following persons and organisations:

Sue Gardner, Department of Civil Engineering, University of Brighton, for providing Figures 1.1 and 1.2; the Ordnance Survey and, in particular, $\mathrm{Mr}$ Adrian Spence, for permission to publish figures 1.3, 1.13, 1.16 and 1.17; the Royal Institution of Chartered Surveyors for providing material on which sections 1.1, 1.2 and 1.3 are based and for permission to publish figure 9.1; Mr Stephen Booth and the Institution of Civil Engineering Surveyors for providing material on which sections 1.1 and 1.4 are based; Mr Stephen Kennedy and Pentak UK Ltd for providing figure 2.9; Ms Deborah Saunders, Mr Alan Murray, Dr Mike Grist and Leica UK Ltd for providing figures $1.4,1.5,2.5,2.11,2.12,2.16,2.17,2.18,2.24,2.30,3.3,3.7,3.8,3.9,3.10$, $3.11,3.14,3.17,3.18,3.20,3.21,3.22,3.32,3.33,5.10$ (a), 5.29, 5.36, 5.37, $7.18,8.1,8.6$ (a), 14.54, 14.61, 14.67, 14.68, 15.1, 15.2, 15.6 and 15.10; $\mathrm{Mr}$ Ralph Tiller, Mr Geoff Sinclair and Sokkia Ltd for providing figures 3.2, $3.5,3.19,3.23,3.24,3.26,3.28,5.7,5.11,5.12$ (b), 5.27, 5.40, 5.41, 5.42, 14.59 and 15.11; Ms Rosanne Pearce and Fisco Products Ltd, for providing figures 4.3, 4.4, 4.5, 4.11 and 4.12; The Building Research Establishment, in particular Dr Beryl Cook, for permission to publish figures 4.8, 4.9 and 15.3; Mr Brian McGuigan and Geotronics Ltd for providing figures 5.10(b), 5.14, 5.15, 5.22, 5.23, 5.24 and 5.34; Mr R.H. Wells, Survey Supplies Ltd, for providing figure 5.12(a); Mr Lawrence Smith and Carl Zeiss Ltd for providing figure 5.12(c); Hall and Watts Ltd for providing figures 5.13 and 5.33; Tellumat Ltd for providing figure 5.26; Husky Computers Ltd for providing figure 5.30; Psion UK PLC for providing figure 5.33; Mike Ewer of Chiltern Survey Equipment Ltd for providing figure 5.38; Ms Helen Knight and Trimble Navigation Europe Ltd for providing figure 8.6(b); Ms T. Hogg of the copy Centre, Headingley, Leeds, for help with section 9.3; Mr Ted Read and LM Technical Services Ltd for providing figure 9.17; Blue Moon Systems Ltd for providing figure 9.18; Mr Colin Beatty and Ashtech for providing figure $8.6(\mathrm{c})$; The Department of Transport for permission to publish tables 11.1, 12.1 and figures 12.4 and 12.5; Mr Katsumi Kaji and 
the Ushikata Mfg Co Ltd, Japan, for providing figure 13.11; Mr J.R. Dixon of the Civil Engineering Department, University of Leeds, for help with section 14.1; figures $14.1,14.7,14.8,14.45$ and 14.51 are reproduced from CIRIA/Butterworths-Heinemann book Setting Out Procedures; The National Swedish Institute for Building Research and, in particular, Dr John van den Berg, for permission to reproduce figures $14.6,14.19,14.21,14.25,14.39$, $14.40,14.14,14.42,14.44,14.47,14.49,14.50,14.55,14.56$ and 14.57; $\mathrm{Mr}$ Trevor Albinson and Pro-Set Proflies Ltd for providing figure 14.23; $\mathrm{Mr}$ Paul Finney and Zenith Surveys Ltd for providing figures 14.52 and 14.65; Mr Jim Pelham and AGL European Lasers Ltd for providing figures 14.62 and 14.64; Ms Nicky Newman and Spectra-Physics Ltd for providing figure 14.66; Mr Paul Kelly and John Kelly (Lasers) Ltd for providing figure 14.71; Mr Chris Boffey of the British Standards Institution for providing information on BS5750; Mr Steve Carey of Construction Instruments Ltd for providing laser diode information; extracts from BS5606: 1990 are reproduced with permission of the British Standards Institution - complete copies can be obtained by post from BSI Sales, Linford Wood, Milton Keynes, MK14 6LE.

Special thanks to Mr Roy Trembath, surveying technician in the Civil Engineering Department at the University of Leeds, for his considerable help with a number of the new photographs and illustrations used in the book.

Every effort has been made to trace all the copyright holders. If any have been inadvertently overlooked, the publishers will be pleased to make the necessary arrangements at the first opportunity. 